\title{
Practical mineralogical quantification of bentonites supported for a PXRD calibrated hkl model
}

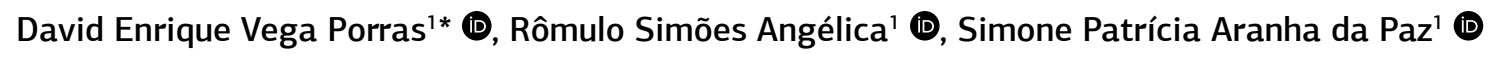

\begin{abstract}
In the bentonite industry - exploration and beneficiation — ore quality control has been traditionally carried out using the swelling parameter, denominating those that swell as naturally sodium bentonites and those that do not as naturally non-sodium bentonites. However, the properties of the bentonites can vary due to the quantity and cationic type of montmorillonite. The variation in those properties cannot always be predicted, because there is still no consolidated and convenient method for clays mineralogical quantification. A quantification via PXRD using the Rietveld method is only reliable when all the crystalline structures of the mineral phases are known. This is not the case for bentonites, since the montmorillonite shows turbostratic disorder that leads to extremely wide and asymmetric non-basal reflections that are not considered in the available structural models. Thus, in this work, is generate a calibrated $h k l$ model for a Brazilian montmorillonite applying the combined Rietveld-Le Bail-Internal Standard method developed by Paz et al. (2018). The study concluded that the combined method is a good choice for the mineralogical quantification of the bentonites, handling turbostratic disorder of montmorillonite, since the develop $h k l$ phase model showed good results in mixtures with $>50 \%$ montmorillonite content (greater precision and reproducibility).
\end{abstract}

KEYWORDS: Bentonite; powder X-ray diffraction; Rietveld method; Le Bail method; internal standard method.

\section{INTRODUCTION}

The term bentonite was first used in 1898 by W.C. Knight to describe a plastic clay located in Benton shale, Rock Creed Region, Wyoming, USA, with the capacity to adsorb large amounts of water and forming thixotropic suspensions (Eisenhour and Brown 2009). Geologically, bentonites are clay rocks composed essentially by Na-montmorillonite, mainly formed from the chemical alteration of volcanic glass of pyroclastic and/or volcanoclastic rocks (Christidis and Huff 2009). However, due to the lack of natural occurrences of bentonites like the North American, the term is generally used for a clay with similar properties consisting essentially of $60-80 \%$ of montmorillonite, which are commercialized regardless of occurrence or geological origin (Grim 1973, Elzea and Murray 1994).

Montmorillonites are dioctahedral 2:1 clay minerals of the smectite group. They are end-members of the montmorillonite-beidellite series with mainly octahedral charge generated by substitution of $\mathrm{Al}^{3+}$ or $\mathrm{Fe}^{3+}$ by $\mathrm{Mg}^{2+}$ and layer charge of 0.2 to $0.6 \mathrm{~mol} /$ f.u. (Emmerich et al. 2009). The features of the smectite group such as the large variability in chemical composition, variable layer charge, octahedral and tetrahedral charges and the Fe content (Wolters et al. 2009) can lead to an unambiguously classification of the dioctahedral types.

\footnotetext{
${ }^{1}$ Universidade Federal do Pará - Belém (PA), Brazil. E-mails: david. porras@ig.ufpa.br, rsangelica@gmail.com,paz@ufpa.br ${ }^{*}$ Corresponding author.
}

According to these features, the Formosa Mg-montmorillonite, a relatively new occurrence from northern Brazil (Paz et al. $2011,2012 a$ ), which is of interest in this work, is classified as a beidellitic montmorillonite with octahedral layer charge of $>50 \%$, Fe content of $<0.30 \mathrm{~mol} /$ f.u., and layer charge between $0.426-0.6 \mathrm{~mol} /$ f.u.

Bentonites are widely used as industrial raw material in a large number of technical applications, due to the physical and chemical properties of montmorillonites that underlie its commercial value. Their major uses are as a thixotropic agent in drilling fluids, iron pelletizing, foundry processes (metal casting binder), filtering, clarifying, decolorizing, odor absorbent, cat litter, paper industry, civil engineering, waterproofing, and many other applications (Odom 1984, Emmerich et al. 2009).

Since the end of $20^{\text {th }}$ century, the uses for bentonite and its consumption have increased dramatically, requiring a special attention to ore quality control. In the bentonite industry exploration and beneficiation - ore quality control has been traditionally carried out using the swelling parameter, denominating those that swell as naturally sodium bentonites and those that do not as naturally non-sodium bentonites. However, the properties of the bentonites can vary widely due to the quantity and cationic type of montmorillonite, as well as the amount of accessory minerals present. These variations cannot always be predicted, because there is no consolidated and convenient method for the mineralogical quantification of clays.

Mineralogical quantification methods are still under development, including imaging analytical techniques and Powder X-ray diffractometry (PXRD) (Scarlett and Madsen 2006, Paz et al. 2018). The latter is considered as the most appropriate routine quantitative analysis method compared to other 
analytical techniques, such as Fourier Transform Infrared spectroscopy (FTIR), chemical analysis, and electron microscopy (Bish and Post 1993, Zhou et al. 2018). However, there are still many uncertainties related to the PXRD technique, even for simple geological matrices (Paz et al. 2018), having many ways to quantify without a reliable method, obtaining results with great variability.

The Rietveld refinement (Rietveld 1969) is one of the most commonly used methods to quantify polycrystalline mixtures via PXRD. This method allows dealing with a wide variety of sample-related effects by using the full diffraction pattern as a whole (Hill and Howard 1987, Scarlett and Mandsen 2006, Paz et al. 2018). Nevertheless, this is only reliable when all the crystalline structures of the mineral phases within the sample are known (Paz et al. 2018, Taylor and Rui 1992). In addition, an important requirement of the method is that the diffraction patterns are formed by well-defined Bragg reflections (Wang et al. 2018).

This is not the case for bentonites, since the montmorillonite shows turbostratic disorder: random rotation and/or translation of individual layers to each other (Biscoe and Warren 1942, Ufer et al. 2008, Wang et al. 2018, Taylor and Matulis 1994), which causes a broad diffraction band as a result of the union of several neighboring reflections ( $\mathrm{Paz}$ et al.2018). This disorder leads to extremely wide and asymmetric non-basal reflections (Ufer et al. 2008) that are not considered in the available Crystallographic Information File of the Inorganic Crystal Structure Database (CIF-ICSD) structural models, having only partial crystallographic information. Additionally, the variety of interchangeable cations in the interlayer space and the isomorphous substitutions occurring in the octahedral and/or tetrahedral sheets affect the position of characteristic reflections during quantification (Zhou et al. 2018).

Due to these characteristics, the diffraction patterns of montmorillonites are more complex than the patterns of crystalline materials (Zhou et al. 2018), making it difficult to quantify the phases using the conventional Rietveld method, which makes the mineralogical quantification of bentonites a major challenge.

An alternative for cases where the crystallographic information is partial has been to combine three widely known and reliable methods used for mineralogical quantification: Rietveld, Le Bail and Internal Standard, prioritizing speed, convenience and quality. Thus, the objective of this work was to generate a calibrated $h \mathrm{kl}$ model for the Formosa $\mathrm{Mg}$-montmorillonite applying the combined Rietveld-Le Bail-Internal Standard method developed by Paz et al. (2018) for the quantification of the main mineral components of bentonite clays.

\section{MATERIALS AND METHODS}

\section{Materials}

High purity fluorite and concentrated $\mathrm{Mg}$-montmorillonite samples (Tab. 1) were used to prepare the standard mixtures presented in Table 2. The Mg-montmorillonite sample was
Table 1. Standard minerals.

\begin{tabular}{lccc}
\hline Mineral & Manufacturer & $\begin{array}{c}\text { Purity } \\
(\%)\end{array}$ & $\begin{array}{c}\text { Particle size } \\
(\boldsymbol{\mu m}) / \mathbf{D}_{\mathbf{9 0}}\end{array}$ \\
\hline Montmorillonite & - & $92.2^{\mathrm{a}}$ & $<28.3$ \\
Fluorite & Sigma-Aldrich & $99.0^{\mathrm{b}}$ & $<40.0$ \\
\hline
\end{tabular}

${ }^{a}$ The montmorillonite impurities were determined using a chemical analysis (XRF) and Mössbauer spectroscopy; ${ }^{\mathrm{b}}$ certified value.

Table 2. Codes and mineral proportions of each standard mixture.

\begin{tabular}{lccc}
\hline \multirow{2}{*}{ Mixture code } & \multicolumn{2}{c}{ Wt $(\%)$} & \\
\cline { 2 - 4 } & Montmorillonite & Fluorite & Impurities \\
\hline Calibration of the & $h k l$ model & & \\
MF8020 & 73.7 & 19.8 & 6.5 \\
Validation of the $h k l$ model & & \\
MF9010 & 82.9 & 9.9 & 7.2 \\
MF8020 & 73.7 & 19.8 & 6.5 \\
MF7030 & 64.5 & 29.7 & 5.8 \\
MF6040 & 55.3 & 39.6 & 5.1 \\
MF5050 & 46.1 & 49.5 & 4.4 \\
MF4060 & 36.9 & 59.4 & 3.7 \\
MF3070 & 27.6 & 69.3 & 3.1 \\
\hline
\end{tabular}

obtained by particle size separation and concentration of the clay fraction $(<2 \mu \mathrm{m})$ from the Formosa bentonite, described for the first time by Paz et al. (2012a).

The occurrence of this bentonite is associated with altered Mesozoic volcanism basalts of the Mosquito formation, from the Parnaíba Sedimentary Basin, in Formosa da Serra Negra County, southern Maranhão State, northern Brazil (Paz et al. 2012a).

The clay fraction $(<2 \mu \mathrm{m})$ was obtained according to the following procedure: $50 \mathrm{~g}$ of the material was dispersed in 200 $\mathrm{mL}$ of deionized water in ultrasonic immersion for $30 \mathrm{~min}$. Then, the material was wet sieved manually to separate the sediment sand fraction ( $>75 \mu \mathrm{m}, 250 \mathrm{mesh})$. Afterward, the suspension was centrifuged for $5 \mathrm{~min}$ at 1,400 rotations per minute (RPM) in a Novatecnica NT820 centrifuge to separate the sedimented silt fraction $(75-2 \mu \mathrm{m})$ from the clay fraction (suspended in the overflow). The overflow was further centrifuged for $10 \mathrm{~min}$ at 2,800 RPM to concentrate the clay fraction $(<2 \mu \mathrm{m})$ and then was dried in an oven at $60^{\circ} \mathrm{C}$. Finally, the concentrated clay fraction was manually pulverized in an agate mortar and to ensure the homogeneity of the sample, quartering was conducted according to the elongated heap method.

Fluorite sample is a reference material produced and certified by the Sigma Aldrich laboratory, Germany. It was used as an internal standard in the calibration of the $h \mathrm{kl}$ model and in the standard mixtures for its validation.

\section{Preparation of standard mixtures}

A series of 7 binary standard mixtures of montmorillonite-fluorite was prepared, weighted in accordance with the 
proportions in Table 2. For the calibration of the $h \mathrm{kl}$ model, three replicates of the MF8020 standard mixture were prepared. A quantity of $3.0000 \pm 0.0006 \mathrm{~g}$ of each replicate was prepared using the composition of two parts of $1.5000 \pm$ $0.0006 \mathrm{~g}$. For validation, $1.5000 \pm 0.0006 \mathrm{~g}$ of each standard mixture were prepared. The mixtures were manually pulverized and homogenized in an agate mortar.

\section{Proposed methodology: the combined Rietveld-Le Bail-Internal Standard Powder X-Ray Diffraction Method}

This method was initially proposed by Paz et al. (2018), which combines three widely known and trustworthy methods used for mineralogical quantification of PXRD results: Rietveld, Le Bail and Internal Standard, prioritizing speed, convenience, and quality in the quantification.

According to the proposed methodology, the first step is to generate a calibrated $h k l$ phase model for montmorillonite, using the Le Bail fitting profile method. Then, the calibrated $h \mathrm{kl}$ model is validated using the Rietveld refinement method, inserting simultaneously the calibrated $h k l$ phase model for montmorillonite and the CIF-ICSD file for fluorite (internal standard).

\section{Equipment}

PXRD measurements were performed using a PANalytical Empyrean divergent beam diffractometer, with a $\theta-\theta$ goniometer, a sealed ceramic Co X-ray tube $(\mathrm{K} \alpha 1=1.78901 \AA)$, with a line focus of $1,800 \mathrm{~W}$, a Fe $\mathrm{k} \beta$ filter, and a PIXcel ${ }^{3 \mathrm{D}}$ area detector, operating in a linear scanning mode (1D), with active length of $3.3473^{\circ} 2 \theta$ ( 255 active channels).

\section{Instrumental conditions for PXRD measurements}

The samples were measured using the following instrumental conditions: $40 \mathrm{kV}, 35 \mathrm{~mA}$, soller slits of $0.04^{\circ} \mathrm{rad}$ (incident and diffracted beams), scan range from 2 to $110^{\circ} 2 \theta$, step size of $0.0066^{\circ} 2 \theta$ with $19.266 \mathrm{~s}$ of time/step in the continuous scanning mode, divergence slit of $14^{\circ}$, anti-scatter slit of $1 / 2^{\circ}$, irradiated sample size of $10 \mathrm{~mm}$, anti-scatter slit for the diffracted beam of $7.5 \mathrm{~mm}$ (PIXcel), and sample spinning 2 rotations/s. The total time of the analysis was approximately $34 \mathrm{~min}$. Data acquisition was carried out with the PANalytical X'Pert Data Collector software version 5.1 a. Instrumental resolution was determined using the $\mathrm{LaB}_{6}$ NIST/SRM 660b standard.

\section{Software}

The mineralogical identification was carried out with the PANalytical X'Pert HighScore Plus software, version 3.0, using the Crystallography Open Database (COD) (Gražulis et al. 2009)

Mineralogical quantification by applying the combined method was performed using the FullProf software, version 2011 (Rodríguez-Carvajal 1993), with the specific graphical interface Full version 2012 (Paz et al. 2012b). The CIF files for montmorillonite, fluorite, and $\mathrm{LaB}_{6}$ are referenced in Table 3.
Table 3. Reference and CIF-ICSD codes for the structural models.

\begin{tabular}{lcc}
\hline Mineral & Reference & CIF-ICSD \\
\hline Montmorillonite & Gournis et al. (2008) & 159274 \\
Fluorite & Hund and Lieck (1952) & 28730 \\
LaB6 & Eliseev et al. (1986) & 40947 \\
\hline
\end{tabular}

CIF: crystallographic information file; ICSD: Inorganic Crystal Structure Database.

\section{Analysis}

\section{Chemical analysis}

The X-ray fluorescence (XRF) spectrometer employed was a wavelength dispersive (WDS) sequential Malvern PANanalytical Axios Minerals model, with a Rhodium (Rh) ceramic X-ray tube operating at a maximum power potential level of $2.4 \mathrm{~kW}$. The specimen was fused with lithium tetraborate- $\mathrm{Li}_{6} \mathrm{~B}_{4} \mathrm{O}_{7}$ (1:6 g sample/flux). Data acquisition was performed using the PANalytical SuperQManager software. For the loss on ignition (LOI) analysis, samples were dried at $105^{\circ} \mathrm{C}$, followed by calcination at $1,020^{\circ} \mathrm{C}$ for 2 hours in a muffle furnace.

\section{Mössbauer spectroscopy}

The spectra were recorded at room temperature (298 K) in a previously pulverized sample, using a conventional spectrometer operating in a constant acceleration mode with triangular reference signals, and ${ }^{57} \mathrm{Co}$ source diffused in a $\mathrm{Rh}$ layer. Data accumulation was performed with a multichannel analyzer with 1,024 channels and a speed range from -11 to $+11 \mathrm{~mm} / \mathrm{s}$. Velocity range was calibrated with respect to the $\alpha$-Fe metallic spectrum collected.

\section{Scanning electron microscopy}

A Zeiss SIGMA-VP scanning electron microscope was used for SEM analysis, operating with a constant accelerating voltage of $20 \mathrm{kV}$. The sample was sprayed over a holder with a double-sided carbon tape and then coated with gold using an Emitech K550X sputter coater.

\section{Fourier transformed infrared spectroscopy}

The Fourier transformed infrared spectroscopy (FTIR) spectra were recorded in a Thermo Scientific Nicolet Is50 FTIR spectrophotometer, in the spectral range of $4,000-400 \mathrm{~cm}^{-1}$ and 100 scans were recorded with a frequency resolution of $4 \mathrm{~cm}^{-1}$. The sample was prepared as pressed $\mathrm{KBr}$ discs (1:200 mg sample/ KBr).

\section{Particle size distribution}

The measurements were conducted in a Malvern MASTERSIZER Hydro 2000MU particle size analyzer, whit measured size range of 0.020 to $2,000.000 \mu \mathrm{m}$. The parameters used were: spherical particle model, rotation of 2,500 RPM, dispersant volume of $800 \mathrm{~mL}$, dispersant refraction index (water) of 1.330, particle refraction index (montmorillonite) of 1.560 according to Mie's theory, ultrasonic immersion time of $1 \mathrm{~min}$, and obscurity range of $5-10 \%$. 


\section{RESULTS AND DISCUSSION}

\section{Reference montmorillonite characterization}

\section{Mineralogical identification (PXRD)}

Predominant Montmorillonite was identified with main peaks at $1.52 \mathrm{~nm}\left(\mathrm{~d}_{001}\right), 0.44 \mathrm{~nm}\left(\mathrm{~d}_{100}\right)$, and $0.15 \mathrm{~nm}\left(\mathrm{~d}_{060}\right)$. Minor phases identified are kaolinite $0.73 \mathrm{~nm}\left(\mathrm{~d}_{002}\right)$, hematite $0.27 \mathrm{~nm}\left(\mathrm{~d}_{104}\right), \mathrm{K}$-feldspar $0.33 \mathrm{~nm}\left(\mathrm{~d}_{220}\right)$, and anatase $0.35 \mathrm{~nm}\left(\mathrm{~d}_{011}\right)$ (Fig. 1).

\section{Chemical analysis}

The chemical composition of the Formosa montmorillonite is shown in Table 4. The main components present are $\mathrm{SiO}_{2}$ and $\mathrm{Al}_{2} \mathrm{O}_{3}$, dominant constituents of all clay minerals. The low percentage of $\mathrm{TiO}_{2}$ corresponds to Anatase, identified by PXRD analysis. It is important to emphasize that the high percentage of $\mathrm{Fe}_{2} \mathrm{O}_{3}$, typical for most Brazilian bentonites, corresponds to the total Fe content. However, Fe is related to at least two different minerals identified by PXRD: montmorillonite and hematite. Typically, in montmorillonite, $\mathrm{Fe}^{2+}$ and $\mathrm{Fe}^{3+}$ can substitute $\mathrm{Al}^{3+}$ in the octahedral sheet (Emmerich et al. 2009). Thus, the Mössbauer spectroscopy was used to distinguish between the Fe related to those two minerals.

\section{Mössbauer spectroscopy}

The Mössbauer spectrum consists of three spectral components: two overlapping $\mathrm{Fe}^{3+}$ doublets and one sextet (Fig. 2).

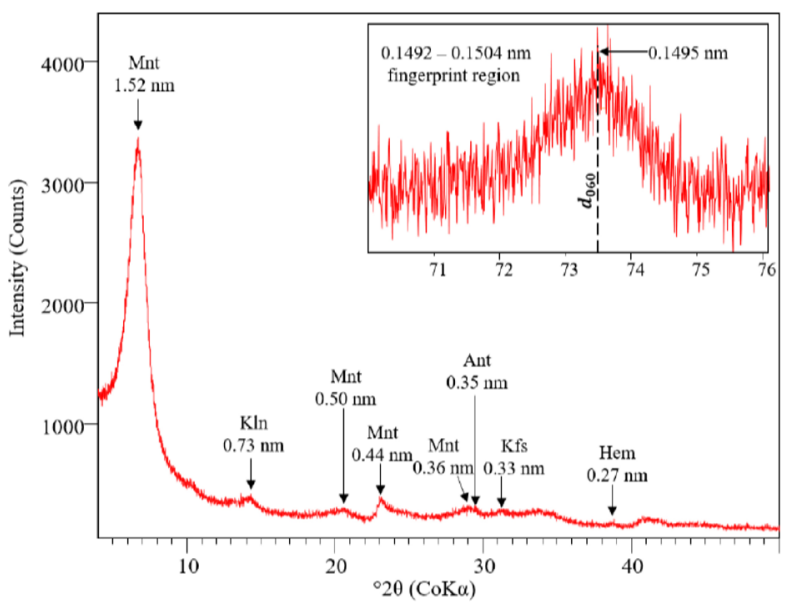

XRD: X-ray diffractometry; Mnt: montmorillonite; Kln: kaolinite; Ant: anatase; Kfs: K-feldspar; Hem: hematite.

Figure 1. XRD pattern of Formosa Mg-montmorillonite and fingerprint region of Montmorillonite.
The inner broad doublet with an isomer shift of $0.38 \mathrm{~mm} / \mathrm{s}$ and a quadrupole splitting of $1.06 \mathrm{~mm} / \mathrm{s}$ is relative to the structural $\mathrm{Fe}^{3+}$ in octahedral position of the montmorillonite. The outer doublet that is much more intense than the inner doublet is related to impurities of amorphous character (with no longrange magnetic ordering) (Cao et al. 1997). Such impurities are present at quantities too low for detection by PXRD analysis. A narrow sextet is attributed to hematite, with a hyperfine magnetic field of $\sim 51.1 \mathrm{~T}$ (Murad and Wagner 1998). The quadrupole splitting of $-0.22 \mathrm{~mm} / \mathrm{s}$ suggests a weakly ferromagnetic state, isomorphic substitutions of $<10 \%$ and/or particle sizes of $>20 \mathrm{~nm}$ (Murad 2010). This mineral was identified at low quantities by PXRD analysis. The Isomer shifts $(\delta)$, quadrupole splitting (D), and peak widths together with the assignment of different components and its percentages of relative spectral area (RA) are summarized in Table 5.

\section{Structural formula calculation}

To ensure that the chemical analysis represents only the montmorillonite's composition, XRF data were corrected using the calibration of the $\mathrm{Fe}_{2} \mathrm{O}_{3}$ result obtained from the Mössbauer analysis. The structural formula calculated by the

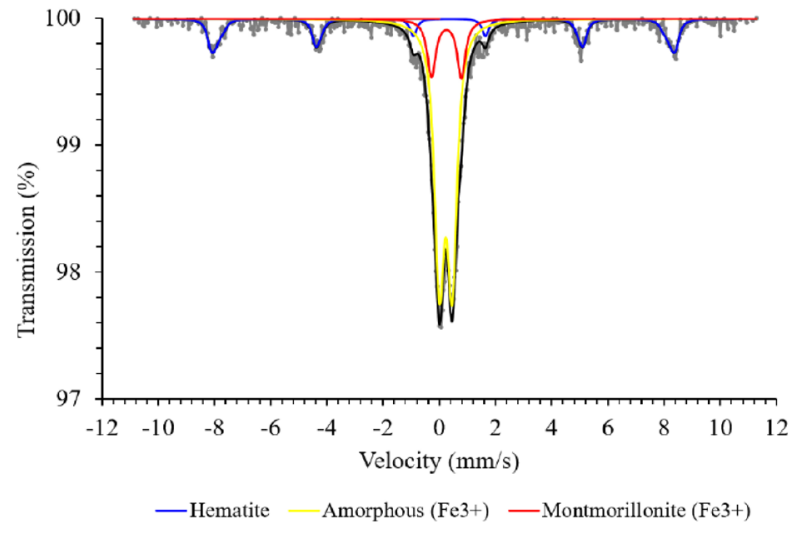

Figure 2. Mössbauer spectra of the Formosa Mg-montmorillonite.

Table 5. Mössbauer parameters determined at $298 \mathrm{~K}$.

\begin{tabular}{lcccc}
\hline $\mathbf{B}_{\mathbf{h f}}{ }^{\mathrm{a}}(\mathbf{T})$ & $\Delta^{\mathrm{b}}(\mathbf{m m} / \mathbf{s})$ & $\delta^{\mathrm{c}}(\mathbf{m m} / \mathbf{s})$ & $\mathbf{R A}^{\mathrm{d}}(\%)$ & Assignment \\
\hline 51.15 & -0.22 & 0.37 & 20.30 & $\begin{array}{c}\text { Hematite } \\
\text { Amorphous } \\
\left(\mathrm{Fe}^{3+}\right)\end{array}$ \\
& 0.40 & 0.36 & 65.70 & $\begin{array}{c}\mathrm{Montmorillonite} \\
\left(\mathrm{Fe}^{3+}\right)\end{array}$ \\
\hline
\end{tabular}

${ }^{a}$ Hyperfine magnetic field; belectric quadrupolar splitting; cisomer shift; ${ }^{\mathrm{d}}$ relative spectral area.

Table 4. Chemical composition of the Formosa Mg-montmorillonite.

\begin{tabular}{lcccccccc}
\hline \multicolumn{6}{l}{ Chemical composition $(\mathbf{W t} \%)$} \\
\hline Component & $\mathbf{S i O}_{2}$ & $\mathbf{A l}_{2} \mathbf{O}_{3}$ & $\mathbf{F e}_{2} \mathbf{O}_{3}$ & $\mathbf{M g O}$ & $\mathbf{C a O}$ & $\mathbf{K}_{\mathbf{2}} \mathbf{O}$ & $\mathbf{T i O}_{2}$ & $\mathbf{L O I}^{\mathbf{a}}$ \\
\hline Mean and SD & $52.4 \pm 0.95$ & $21.5 \pm 0.45$ & $7.6 \pm 0.17$ & $4.5 \pm 0.04$ & $0.3 \pm 0.01$ & $0.8 \pm 0.05$ & $0.3 \pm 0.01$ & $12.1 \pm 1.07$ \\
\hline
\end{tabular}

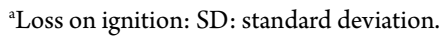


method of Ross and Hendricks (1945) is $\left(\mathrm{Mg}_{0.19} \mathrm{Ca}_{0.02} \mathrm{~K}_{0.07}\right)$ $\left(\mathrm{Al}_{1.64} \mathrm{Fe}_{0.06} \mathrm{Mg}_{0.30}\right)\left(\mathrm{Si}_{3.80} \mathrm{Al}_{0.20} \mathrm{O}_{10}\right)(\mathrm{OH})_{2 .}$. The sums of octahe$\mathrm{dral}$ and tetrahedral cations are 2 and $4 \mathrm{~mol} / \mathrm{f}$.u., respectively, the ideal values for dioctahedral smectites (Schultz 1969). The total layer charge is $-0.5 \mathrm{~mol} / \mathrm{f}$.u., which is balanced by the charge on the interlayer cations $(0.5 \mathrm{~mol} /$ f.u. $)$.

Substitutions of $0.30 \mathrm{Mg}^{2+}$ and $0.06 \mathrm{Fe}^{3+}$ for $\mathrm{Al}^{3+}$ in the octahedral sheet accounts for $60.16 \%$ of the total layer charge. The $39.84 \%$ of the total layer charge is due to $0.20 \mathrm{Al}^{3+}$ for $\mathrm{Si}^{4+}$ substitution in the tetrahedral sheet. $\mathrm{Fe}^{3+}<0.3 \mathrm{~mol} /$ f.u. and $\mathrm{Al}$ $>1.4 \mathrm{~mol} / \mathrm{f}$.u. indicate that the sample is cis-vacant (Wolters et al. 2009). According to Emmerich et al. (2009), smectite can be classified as a highly charged beidellitic montmorillonite (Tab. 6).

\section{Scanning electron microscopy}

Figure 3 shows the SEM micrographs of the Formosa montmorillonite with typical smectite morphology: very extensive stacking of the sheets, evidenced by large undulations and tactoids, tactoids inside the aggregates, and arrangement of aggregates inside the clusters (Souza Santos 1989, Neaman et al. 2003, Paz et al. 2011).

\section{Fourier transformed infrared spectroscopy}

The FTIR spectrum is shown in Fig. 4, with the following typical absorption bands assigned for montmorillonite (Van der Marel and Beutelspacher 1976): 3,622 cm cm $^{-1} \mathrm{OH}$ stretching of structural hydroxyl groups), $\sim 3,428 \mathrm{~cm}^{-1}$ (OH stretching of water), $\sim 1,642 \mathrm{~cm}^{-1}$ (OH deformation of water), $\sim 1,031 \mathrm{~cm}^{-1}$ (Si-O stretching), $\sim 911 \mathrm{~cm}^{-1}$ (Al-OH-Al deformation), $\sim 695 \mathrm{~cm}^{-1}$ (Si-O structural stretching), $\sim 529 \mathrm{~cm}^{-1}$ (Al-O-Si deformation), and $\sim 467 \mathrm{~cm}^{-1}$ (Si-O-Si deformation). The band at $\sim 3,700 \mathrm{~cm}^{-1}$ (OH stretching) was assigned for kaolinite, identified by PXRD analysis.

\section{Particle size distribution}

Particle Size Distribution (PSD) curves (Fig. 5) show a particle size range from $\sim 0.3$ to $\sim 100 \mu \mathrm{m}$ and $\sim 60 \%$ (by number) of the particles are $<10 \mu \mathrm{m}$ (ideal particle size). The frequency distribution curve exhibits a monomodal lognormal distribution with the local maxima at $8.9 \mu \mathrm{m}$ and $\sim 54 \%$ particles are
Table 6. Classification of dioctahedral smectites ${ }^{\mathrm{a}}$.

\begin{tabular}{|c|c|c|}
\hline Property & & Classification \\
\hline \multicolumn{3}{|c|}{ Layer charge (mol/f.u.) } \\
\hline $0.2-0.374$ & & Low-charged \\
\hline $0.375-0.425$ & & Medium-charged \\
\hline $0.426-0.600$ & & High-charged \\
\hline \multicolumn{3}{|c|}{ Fe content (mol/f.u.) } \\
\hline $0-0.30$ & & -- \\
\hline $0.31-1$ & & Ferrian \\
\hline \multicolumn{3}{|c|}{ Charge location (\%) } \\
\hline Octahedral & Tetrahedral & \\
\hline $90-100$ & $0-10$ & Montmorillonite \\
\hline $50-89$ & $11-50$ & Beidellitic montmorillonite \\
\hline $10-49$ & $51-90$ & Montmorillonitic beidellite \\
\hline $0-9$ & $91-100$ & Beidellite \\
\hline
\end{tabular}

${ }^{\mathrm{a} E m m e r i c h ~}$ et al. (2009).

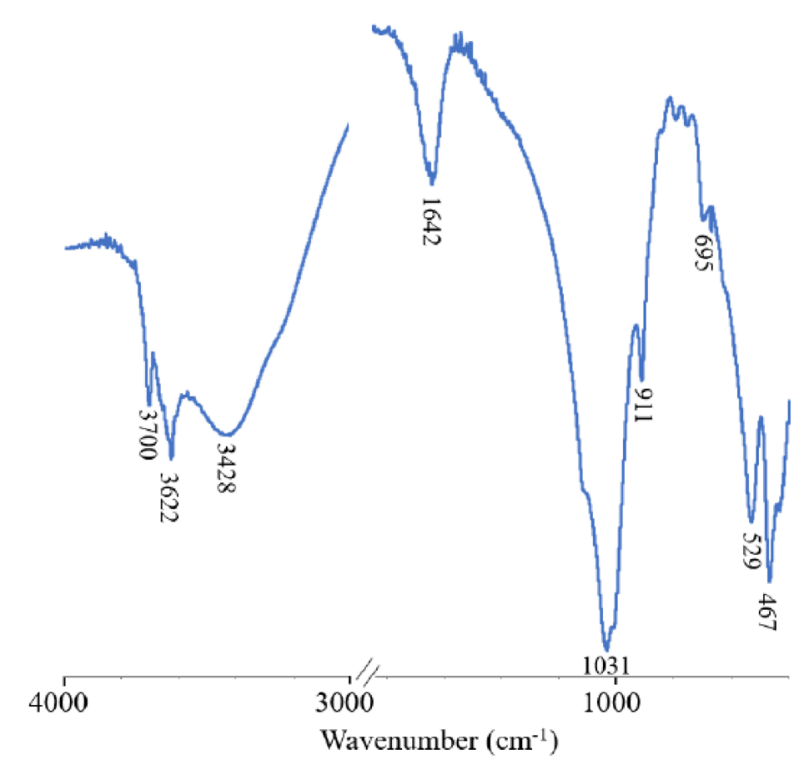

Figure 4. Fourier Transform Infrared spectroscopy spectra of the Formosa Mg-montmorillonite.
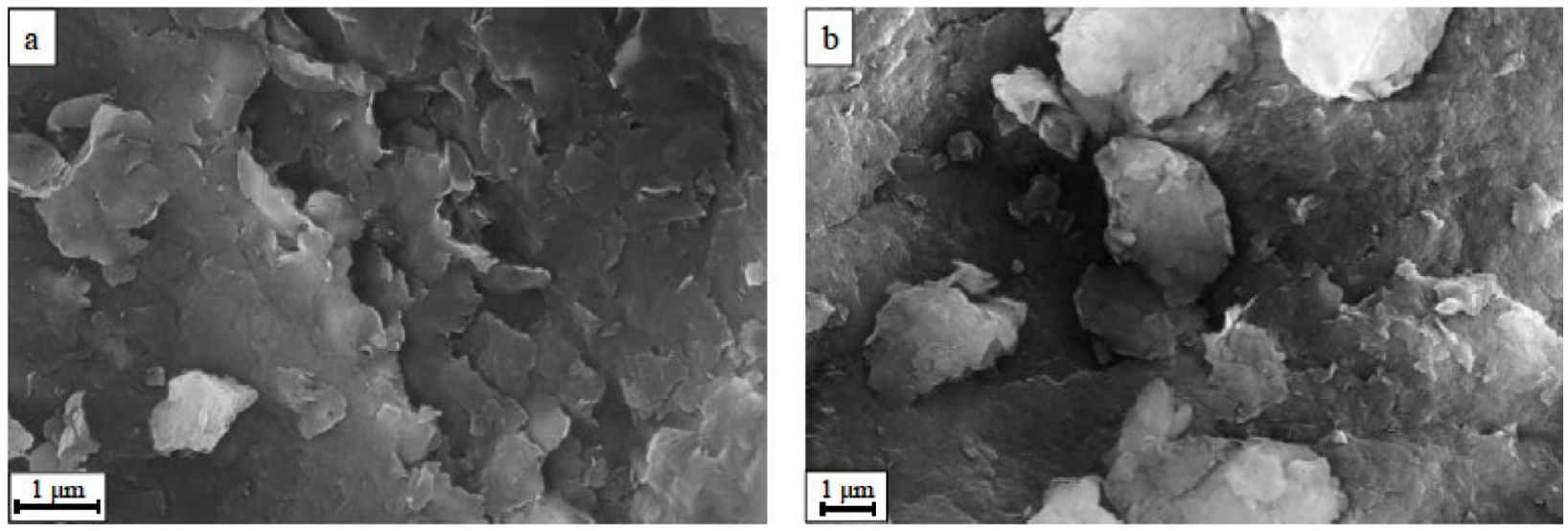

Figure 3. Scanning electron microscopy micrographs of the Formosa Mg-montmorillonite. 


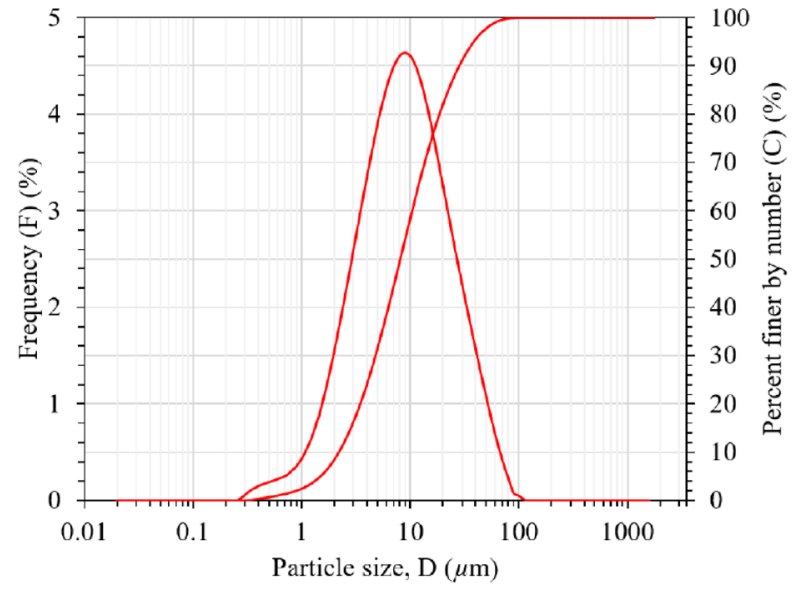

C: cumulative percentage; F: occurrence frequency of each size.

Figure 5. PSD curves of the Formosa Mg-montmorillonite.

finer than this value. This distribution curve together with the coefficient of uniformity $(>4)$ and the coefficient of curvature $(\sim 1)$ indicate a well-graded sample with a homogeneous particle size distribution (ASTM 2011).

The average particle size of $13.08 \mu \mathrm{m}$ and the $\mathrm{D}_{90}>28.34 \mu \mathrm{m}$, suggest an acceptable particle size distribution for the mineralogical quantification, considering that all particles are $<50 \mu \mathrm{m}$ (Payzant 2008). These values show that the preparation method (manual pulverization-homogenization) was excellent, allowing to reduce errors associated to particle size. Table 7 summarizes the PSD parameters.

\section{Calibrated hkl phase model for montmorillonite}

Figure 6 shows the diffraction pattern of the Formosa Mg-montmorillonite with the lines of a similar montmorillonite indexed standard (ICSD-CIF 159274).

Significant discrepancies were observed in the relative intensities and in the peak positions when comparing both diffraction patterns. These differences reveal a lack of crystalline structure information related to structural defects and divergences in unit cell dimensions and spatial groups ( $\mathrm{Paz}$ et al. 2018).

The Formosa Mg-montmorillonite exhibit a turbostratic stacking disorder which causes a broad diffraction band in the region $22-37^{\circ} 2 \theta \mathrm{CoK} \alpha$ (Highlighted region in Fig. 6). It is the most severe kind of layer stacking disorder, defined as a random rotation and/or translation of the individual layers tetrahedral-octahedral-tetrahedral (TOT) to each other in the a-b plane (Fig. 7) (Biscoe and Warren 1942, Ufer et al. 2009, Wang et al. 2018).

The broad diffraction band region shows a typically broadened peak with strong asymmetry (Ufer et al. 2009, Wang et al. 2018), without the complete design of each of them up to the background line (Angélica et al. 2018, Paz et al. 2018). This effect difficults the use of the conventional Rietveld method, as the method allows dealing with phases which contain only minor disorders. However, it presents severe problems of adjustment when dealing with severe disorders such
Table 7. Particle size distribution parameters for the Formosa Mg-montmorillonite.

\begin{tabular}{|c|c|c|c|c|c|c|c|}
\hline $\begin{array}{l}\text { PSD } \\
(\mu \mathrm{m})\end{array}$ & & & & & & $\mathbf{C}_{\mathrm{u}}{ }^{\mathrm{a}}$ & $\mathbf{C}_{c}{ }^{b}$ \\
\hline$D_{10}$ & $\mathbf{D}_{30}$ & $D_{50}$ & $D_{60}$ & $D_{90}$ & Average & $\begin{array}{c}D_{60} / \\
D_{10}\end{array}$ & $\begin{array}{c}D_{30}{ }^{2} / \\
\left(D_{10}^{*} D_{60}\right)\end{array}$ \\
\hline 2.21 & 4.83 & 8.16 & 10.50 & 28.34 & 13.08 & 4.76 & 1.01 \\
\hline
\end{tabular}

as turbostratic disorder, preventing the correct determination of the phase content (Ufer et al. 2009, Ufer et al. 2008). For a successful refinement by the Rietveld method, it is necessary that the structural model must be as similar as possible to the measured diffraction pattern. This is not the case of montmorillonite, because the complex region of the diffraction band is not adequately considered in the available structural models. Moreover, the montmorillonite is characterized by a small tactoid size, which combined with the turbostratic disorder make it difficult to develop a proper structural model in terms of atomic coordinates $(x, y, z)$, with reliable thermal and occupational factors (Dermatas and Dadachov 2003).

Nevertheless, a successful quantitative analysis for mineralogical phases with partial crystallographic information is possible by combining the Rietveld, Le Bail, and Internal Standard methods (Paz et al. 2018).

Concerning the Le Bail profile fitting (Le Bail et al. 1988), an $h k l$ model is developed from a prepared mixture with known amounts of the phase of interest plus a well-characterized standard material (Paz et al. 2018). In this method, peak positions of the phase of interest are limited according to the space group, while allowing variations in the peak individual intensities and the scale factor that represents an empirical structure factor related to the concentration of the phase is derived (Scarlett and Madsen 2006, Paz et al. 2018). This $h k l$ model is used in the Rietveld refinement for quantitative phase analysis.

The ICSD-CIF 159274 (Gournis et al. 2008) structural model was the most compatible with the Formosa Mg-montmorillonite among the models available in the ICSD database. Thus, unit cell dimension data and the space group were used to generate the calibrated $h k l$ model.

Accordingly, using the Le Bail method, an $h k l$ model for montmorillonite was generated and calibrated from the standard binary mixture MF8020 (montmorillonite $73.7 \%$, fluorite $19.8 \%$, impurities $6.5 \%$ ). An average scale factor of $2.96 \times 10^{-4}$ for montmorillonite was manually adjusted at the end of the refinement, and the average scale factor of $4.07 \times 10^{-4}$ for fluorite was calibrated from the known mass fraction. The resultant $h k l$ file contains a list of 195 effective reflections, with the information of the $h k l$ planes, multiplicity, peak position, and absolute intensities (Fig. 8).

A good fit of the model (Fig. 9) was obtained when the initial interval of 22.4-23.1 ${ }^{\circ} 2 \theta \mathrm{CoK} \alpha$ of the diffraction band was excluded. The background was adjusted by the adjustable points method, with the manual insertion of 15 points in free positions, and the profile was adjusted using the Thompson 


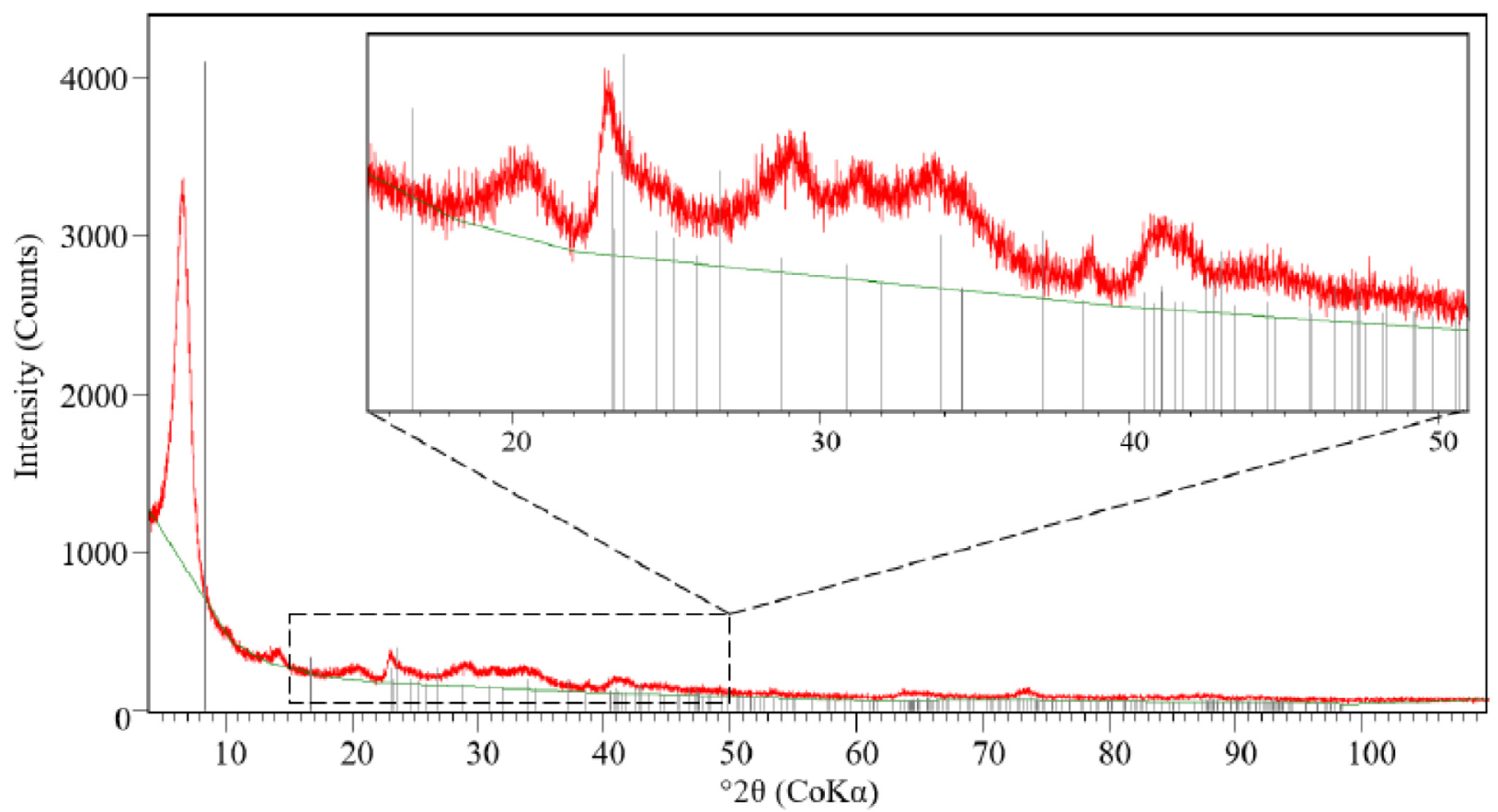

Source: Gournis et al. (2008).

XRD: X-ray diffractometry; CIF: crystallographic information file; ICSD: Inorganic Crystal Structure Database.

Figure 6. XRD pattern of the Formosa Mg-montmorillonite (red) overline with an indexed pattern ICSD-CIF 159274 (gray).

\section{Tactoid}

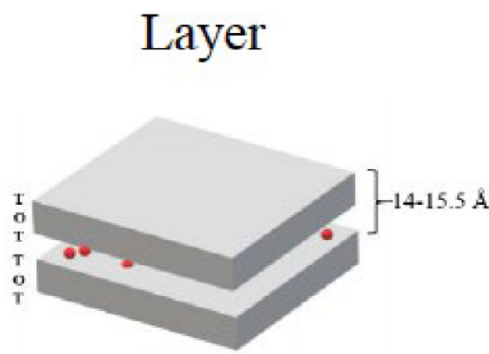

Turbostratic disorder
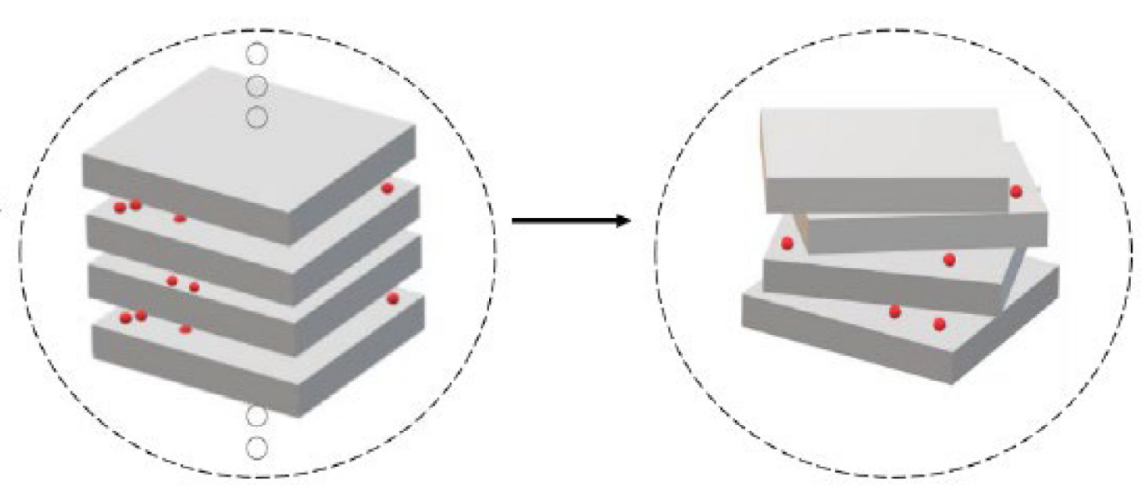

T: tetrahedral sheet; O: octahedral sheet.

Figure 7. Structural units of montmorillonite.

Cox Hastings function $(\mathrm{TCH})$, without considering the structural information (atomic coordinates), which significantly reduces the number of parameters to be refined.

The method was reproducible for three replicates of the MF8020 mixture (A, B and C) (Tab. 8), obtaining statistical indices of refinement $\chi^{2}=\left(R_{\mathrm{wp}} / R_{\text {exp }}\right)^{2}$ and $R_{\text {Bragg }}$ lower than 5, which were considered satisfactory (Tab. 9). The stability and greater precision along with the speed and convenience of the results show that the combined method is a good choice to be considered in the industry for the mineralogical quantification of bentonites.

\section{Summary of refined parameters in generating the} calibrated hkl phase model for montmorillonite

For the construction of the $h k l$ phase model, the Pseudo-Voigt and $\mathrm{TCH}$ peak profile functions were tested. According to the graphical adjustment, the visual inspection of the residue and the statistical errors $\left(R_{\mathrm{Bragg}}, R_{\mathrm{wp}}, R_{\exp }\right.$ and $\left.\chi^{2}\right)$, the TCH function was the best option to refine the peak shape of the montmorillonite and fluorite. It gave a better matching to the experimental diffraction lines, without extending the convergence time of this multi-parametric system (Gournis et al. 2008). This function allows analyzing the tactoid-size and strain broadening effects (Thompson et al. 1987).

To ensure greater stability of the method a parameter was included at each step. In each of the refined parameters, the iterative adjustment calculation was executed for several cycles until full convergence.

The $h k l$ model was generated according the following best refinement sequence: starting with the Rietveld method for the two phases (montmorillonite and fluorite). The first parameter refined was the sample displacement. After refining that, 


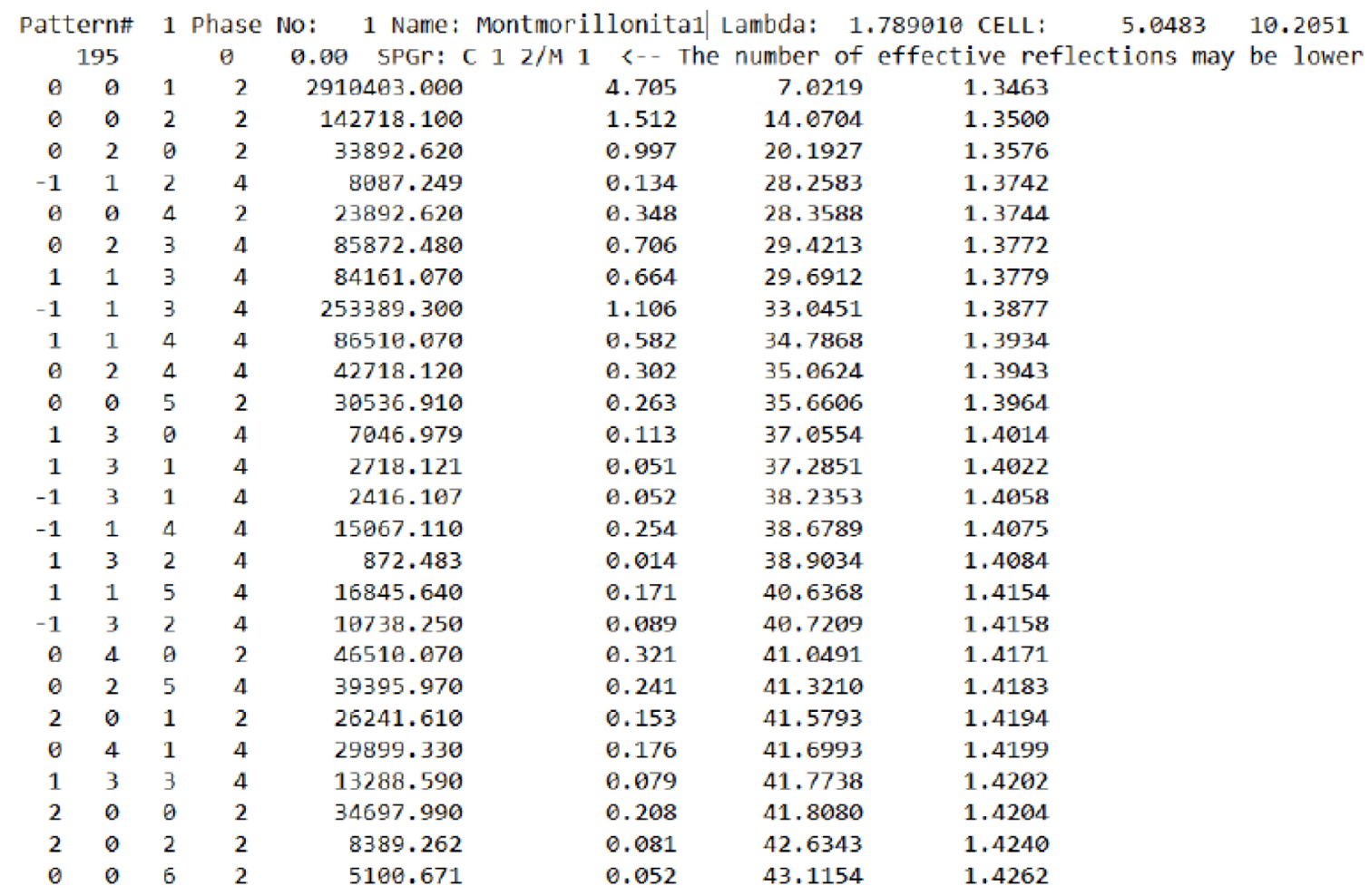

Figure 8. Calibrated $h k l$ file for the Mg-montmorillonite.

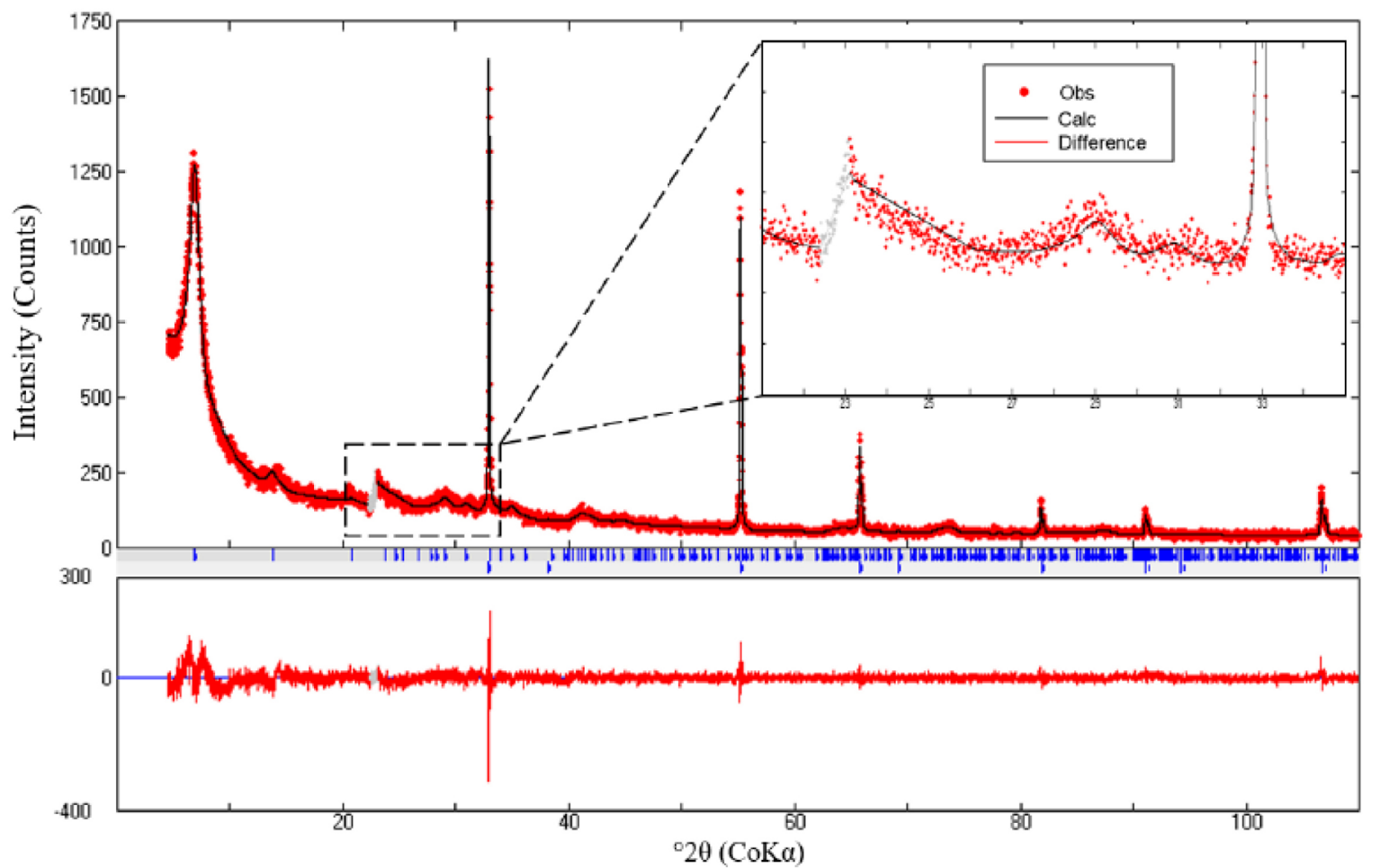

Figure 9. Rietveld-Le Bail refinement plot of the MF8020 mixture and residual. Highlight shows a good fit in the broad diffraction band region $\left(22-37^{\circ} 2 \theta \mathrm{CoK} \alpha\right)$.

the relaxation factors for the profile fitting, and atomic and global parameters were reduced from 0.99 to 0.2 . The background was initially adjusted by the polynomial function with five coefficients.

Subsequently, the small region at the beginning of the montmorillonite diffraction band was excluded (22.4 to $23.1^{\circ}$
$2 \theta \operatorname{CoK} \alpha)$. Removal this interval means that only the upper part of the intensities is considered in the $h k l$ model, and the lower part is considered as a background (Paz et al. 2018).

Afterward, the polynomial function of the background was changed to a linear interpolation with given points, with the simultaneous manual insertion of 15 points in the diffraction 
Table 8. Reflection intensities using the Le Bail method (7-41 $\left.{ }^{\circ} 2 \theta \mathrm{CoK} \alpha\right)$ and unit cell dimensions of the calibrated $h k l$ phase model calibrated for Mg-montmorillonita (Triplicate: A, B and C).

\begin{tabular}{|c|c|c|c|c|c|}
\hline \multirow{2}{*}{$h k l$} & \multirow{2}{*}{${ }^{\circ} 2 \theta(\operatorname{CoK} \alpha)$} & \multicolumn{3}{|c|}{ Relative intensity (\%) } & \multirow{2}{*}{$\operatorname{Mean}(S D)$} \\
\hline & & $h k l$ model A & $h k l$ model B & $h k l$ model C & \\
\hline 001 & 7.00 & 100 & 100 & 100 & $100(0)$ \\
\hline 002 & 14.03 & 4.23 & 4.90 & 5.98 & $5.04(0.88)$ \\
\hline 020 & 20.26 & 0.76 & 1.16 & 2.29 & $1.41(0.79)$ \\
\hline 004 & 28.28 & 0.67 & 0.82 & 1.71 & $1.07(0.56)$ \\
\hline 113 & 29.64 & 1.70 & 2.89 & 3.30 & $2.63(0.83)$ \\
\hline-113 & 32.88 & 7.09 & 8.71 & 7.95 & $7.92(0.81)$ \\
\hline 130 & 37.07 & 0.12 & 0.24 & 0.75 & $0.37(0.34)$ \\
\hline-131 & 38.23 & 0.13 & 0.08 & 0.26 & $0.16(0.09)$ \\
\hline-114 & 38.49 & 0.12 & 0.52 & 0.62 & $0.42(0.26)$ \\
\hline 132 & 38.94 & 0.30 & 0.03 & 0.38 & $0.24(0.18)$ \\
\hline 115 & 40.58 & 1.24 & 0.58 & 0.06 & $0.63(0.59)$ \\
\hline Lattice parameters & & $h k l$ model A & $h k l$ model B & $h k l$ model C & Mean (SD) \\
\hline \multirow[t]{3}{*}{$\AA$} & a & 5.025 & 5.048 & 5.159 & $5.08(0.07)$ \\
\hline & $\mathrm{b}$ & 10.264 & 10.205 & 10.054 & $10.17(0.11)$ \\
\hline & c & 14.754 & 14.706 & 14.763 & $14.74(0.03)$ \\
\hline \multirow[t]{3}{*}{ o } & $\alpha$ & 90.000 & 90.000 & 90.000 & $90.00(0)$ \\
\hline & $\beta$ & 84.597 & 83.329 & 82.621 & $83.52(1)$ \\
\hline & $\gamma$ & 90.000 & 90.000 & 90.000 & $90(0)$ \\
\hline
\end{tabular}

SD: standard deviation.

Table 9. Error statistic indices and scale factor values obtained by Le Bail profile fitting, calibrated $h k l$ phase model for Mg-montmorillonite (Triplicate: A, B and C).

\begin{tabular}{lccccccccc}
\hline \multirow{2}{*}{$\begin{array}{l}\boldsymbol{k} \boldsymbol{l} \boldsymbol{m} \\
\text { model }\end{array}$} & \multicolumn{2}{c}{ Component (wt\%) } & \multicolumn{2}{c}{ Scale factor } & \multicolumn{2}{c}{ Error indices (\%) } & \multicolumn{2}{c}{$\mathbf{R}_{\text {Bragg }}$} \\
\cline { 2 - 10 } & Montmorillonite & Fluorite & Montmorillonite & Fluorite & $\mathbf{R}_{\text {wp }}$ & $\mathbf{R}_{\exp }$ & $\chi^{2}$ & Montmorillonite & Fluorite \\
\hline A & 73.7 & 19.8 & $3.03 \times 10^{-4}$ & $4.15 \times 10^{-4}$ & 30.10 & 29.70 & 1.03 & 0.41 & 3.91 \\
B & 73.7 & 19.8 & $2.98 \times 10^{-4}$ & $4.10 \times 10^{-4}$ & 30 & 29.50 & 1.03 & 0.37 & 3.51 \\
C & 73.7 & 19.8 & $3.00 \times 10^{-4}$ & $3.96 \times 10^{-4}$ & 28.60 & 27.30 & 1.10 & 0.22 & 4.64 \\
\hline
\end{tabular}

pattern at peak-free positions, which were not refined initially. The insertion of the adjustable points allows to consider the background as a discontinuous function (two continuities). This step is necessary due to the removal of the small region at the beginning of the diffraction band.

The first refined phase is the one with the highest concentration, in this case, montmorillonite. Due to the small tactoid size and the turbostratic disorder, the montmorillonite phase exhibits cell unitary defects and asymmetric and broad peaks.

Therefore, beginning with the Rietveld method, unit cell parameters $(a, b, c, \beta)$ were the first parameters to be refined. Afterward, the $\mathrm{Y}$ factor in the TCH function that corresponds to the tactoid size was refined. The third largest effect of the montmorillonite phase on the diffraction pattern was the peak asymmetry that was refined in the $\mathrm{TCH}$ function (two asymmetry factors). Consequently, the montmorillonite refinement was changed from the Rietveld refinement to fitting profile Le
Bail method (profile matching S = Cte, in FULL interface) and then, the unitary cell content was informed (calculated structural formula).

As regards fluorite, no significant discrepancies were observed between the diffractometric profile observed and the structural model used (CIF-ICSD 28730). However, a characteristic feature of fluorite is the broad peaks caused by microstrain. Therefore, this was the parameter refined, adjusted by the $\mathrm{X}$ and $\mathrm{U}$ parameters of the $\mathrm{TCH}$ function and two asymmetry factors.

Subsequently, the background was refined, leaving the extreme points of the two continuities fixed. Finally, with the best-fitted diffraction model, the montmorillonite scale factor was manually modified until a standard mass value of montmorillonite equal to $73.7 \%$ was obtained. Then, the * ${ }^{*}$ hkl file (calibrated $h k l$ phase model for montmorillonite) was created (Fig. 8). 


\section{Validation of the calibrated hkl phase model for montmorillonite}

The method was reproducible for three replicates of the binary mixtures MF8020. The statistical indices of the refinement were satisfactory since the global index $\chi^{2}$ for each mixture was $\sim 1$ and the $R_{\text {Bragg }}$ of the two phases was $\leq 5$ (Tab. 10).

Figure 10 represents the residual plot for each quantified mixture (residual difference between the standard mass and estimated mass values). A random distribution and the absence of trend behavior observed in the mixtures with $>50 \%$ of montmorillonite, show statistical independence of the residues. The difference between the calculated mass fraction and the standard mass fraction in these mixtures was below $\pm 2.5 \%$. The global indices $\chi^{2}$ for each mixture were considered satisfactory since the values were $<5$. As regards $R_{\mathrm{Bragg}}$ indices for each phase, the values tend to be high when the phase concentration is low, not only because of the lack of fit (Tab. 11) (Paz et al. 2018).
Regarding the binary mixtures with $<50 \%$ of montmorillonite, an underestimation of the expected value was observed (Tab. 10). This is due to the fact that the number of effective reflections decreases as the phase concentration decreases, affecting the success and stability of the refinement, without having a full convergence in each of the refined parameters.

\section{Summary of the refined parameters in the quantification of the montmorillonite and fluorite binary mixtures}

The refinement sequence for the quantification of the binary mixtures was the same used in the generation of the $h k l$ model, but, this time, already using the calibrated $h k l$ phase model for montmorillonite. It is important to emphasize that the removal of the initial region of the broad diffraction band is necessary along with the adjustment of the background using a linear interpolation between the given points.

Table 10. Quantitative results of the standard mixture MF8020, difference between the standard mass and estimated mass values, and statistic error indices of the Rietveld refinement using the calibrated $h k l$ phase model for Mg-montmorillonite (Triplicate: A, B and C).

\begin{tabular}{|c|c|c|c|c|c|c|c|c|c|}
\hline \multirow{2}{*}{$\begin{array}{l}\text { Mixture } \\
\text { standard }\end{array}$} & \multicolumn{2}{|c|}{ Component (wt\%) } & \multicolumn{2}{|c|}{ Difference (wt\%) } & \multicolumn{3}{|c|}{$\begin{array}{c}\text { Error indices } \\
(\%)\end{array}$} & \multirow{2}{*}{$\begin{array}{c}\mathbf{R}_{\text {Bragg }} \\
\text { Montmorillonite }\end{array}$} & \multirow[t]{2}{*}{ Fluorite } \\
\hline & Montmorillonite & Fluorite & Montmorillonite & Fluorite & $\mathbf{R}_{w p}$ & $\mathbf{R}_{\exp }$ & $\chi^{2}$ & & \\
\hline \multirow[t]{2}{*}{ MF8020 } & Standard value & & & & & & & & \\
\hline & 73.7 & 19.8 & & & & & & & \\
\hline Measure & Standard value & & & & & & & & \\
\hline 1 & 75.0 & 18.4 & -1.3 & 1.4 & 28.4 & 28.4 & 1.0 & 4.4 & 4.9 \\
\hline 2 & 74.9 & 18.5 & -1.2 & 1.3 & 28.8 & 28.6 & 1.0 & 3.5 & 3.8 \\
\hline 3 & 74.8 & 18.6 & -1.1 & 1.2 & 29.4 & 29.0 & 1.0 & 5.1 & 5.2 \\
\hline Mean and SD & $74.9 \pm 0.1$ & $18.5 \pm 0.1$ & & & & & & & \\
\hline
\end{tabular}

SD: standard deviation.

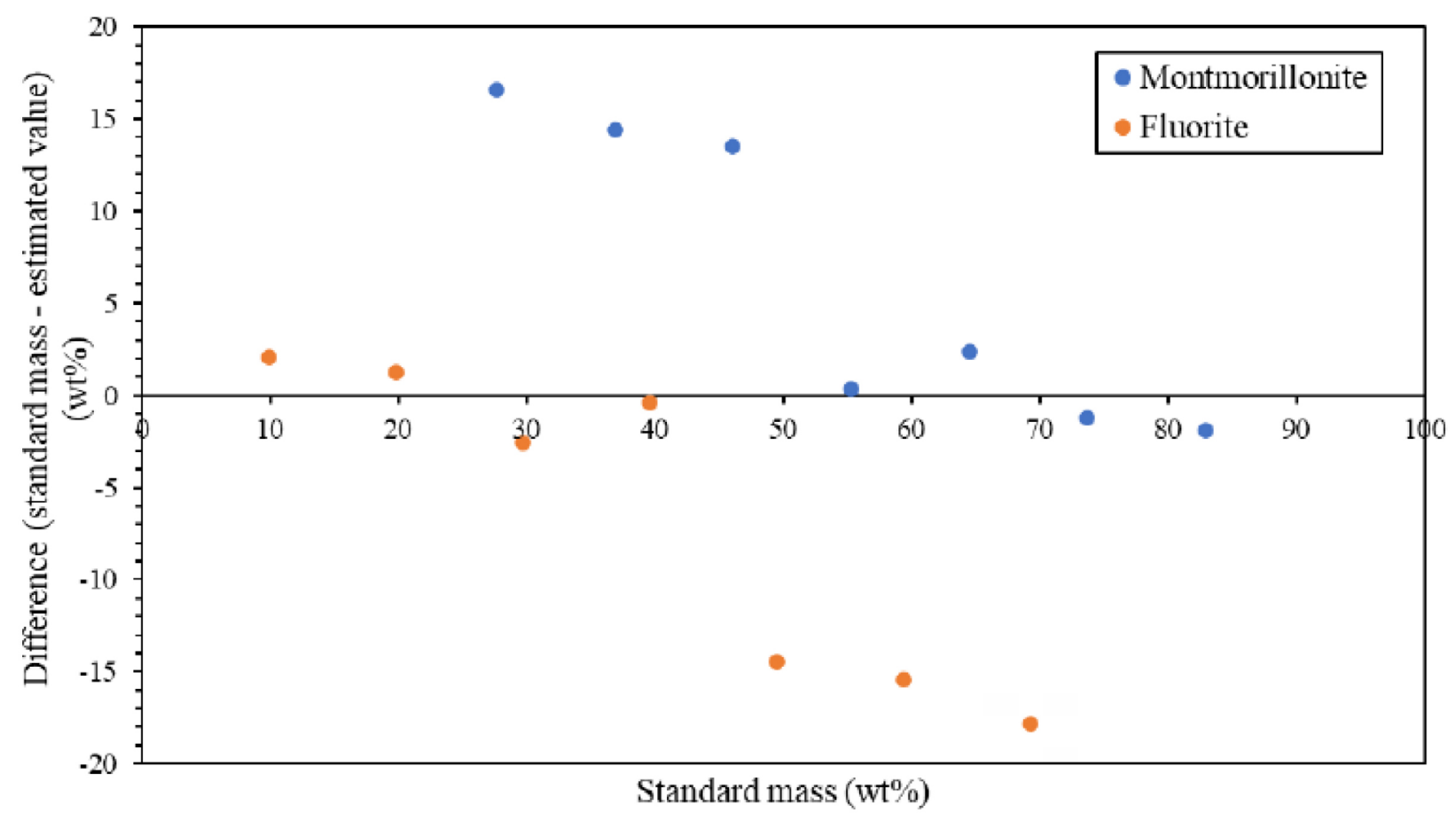

Figure 10. Residual plot of quantification of seven standard binary mixtures using the calibrated $h k l$ file generated for $\mathrm{Mg}$-montmorillonite. 
Table 11. Quantitative result of the binary mixtures and statistic error indices of the Rietveld refinement using the calibrated $h k l$ phase model for Mg-montmorillonite.

\begin{tabular}{|c|c|c|c|c|c|c|c|c|c|}
\hline \multirow{3}{*}{ Mixture } & \multicolumn{4}{|c|}{ Component (wt\%) } & \multicolumn{3}{|c|}{ Error indices (\%) } & \multirow{2}{*}{\multicolumn{2}{|c|}{$\mathbf{R}_{\text {Bragg }}$}} \\
\hline & \multicolumn{2}{|c|}{ Montmorillonite } & \multicolumn{2}{|c|}{ Fluorite } & \multirow{2}{*}{$\mathbf{R}_{w p}$} & \multirow{2}{*}{$\mathbf{R}_{\text {exp }}$} & \multirow{2}{*}{$\chi^{2}$} & & \\
\hline & Standard & Estimated & Standard & Estimated & & & & Montmorillonite & Fluorite \\
\hline MF9010 & 82.9 & 84.9 & 9.9 & 7.8 & 32.2 & 25.6 & 1.6 & 11.2 & 16.9 \\
\hline MF8020 & 73.7 & 74.9 & 19.8 & 18.5 & 28.8 & 28.6 & 1.0 & 3.5 & 3.8 \\
\hline MF7030 & 64.5 & 62.1 & 29.7 & 32.3 & 30.5 & 29.9 & 1.0 & 6.7 & 4.7 \\
\hline MF6040 & 55.3 & 54.9 & 39.6 & 40.0 & 32.0 & 29.6 & 1.2 & 7.5 & 6.0 \\
\hline MF5050 & 46.1 & 35.5 & 49.5 & 60.9 & 32.8 & 30.2 & 1.2 & 11.9 & 5.2 \\
\hline MF4060 & 36.9 & 22.5 & 59.4 & 74.8 & 29.1 & 28.9 & 1.0 & 22.7 & 4.8 \\
\hline MF3070 & 27.6 & 11.1 & 69.3 & 87.1 & 28.5 & 28.5 & 1.0 & 34.6 & 3.6 \\
\hline
\end{tabular}

\section{CONCLUSIONS}

The combined Rietveld-Le Bail-Internal Standard method of Paz et al. (2018) — for the purpose of mineralogical quantification - was successfully reproduced in this work. The calibrated $h k l$ phase model developed can be used for the mineralogical quantification of bentonites, due to the reproducibility and greater precision in the results. The exclusion of a poorly resolved montmorillonite peak helped to solve the lack of fit in the complex region of the diffraction band, handling turbostratic disorder of montmorillonite, without hampering the generation of the $h \mathrm{kl}$ model. These results make the combined method a good choice for the bentonite industry, being convenient and fast.

According to the chemical analysis, the Formosa Mg-montmorillonite was classified as highly charged beidellitic montmorillonite. Knowing the degree of purity of the sample was a fundamental requirement for the development of the calibrated $h k l$ model. However, the chemical composition did not influence the validation of the calibrated $h k l$ model using the combined method.

\section{ACKNOWLEDGMENTS}

This study was partly funded by the Coordenação de Aperfeiçoamento de Pessoal de Nivel Superior (CAPES) — Finance Code 001, along with a scholarship to the first author. We also thank the Conselho Nacional de Desenvolvimento Científico e Tecnológico (CNPq) for its financial support: Edital Universal MCTI/CNPq No. 01/2016 (Grant 402.427/2016-5) and No. 01/2018 (Grant 429.756/2018-6).

\section{ARTICLE INFORMATION}

Manuscript ID: 20200088. Received on: 08/20/2020. Approved on: 10/25/2020.

D.E.V.P. did the investigation, data curation, wrote the paper, and prepared the Figures. S.P.A.P. conceived the work and did the sampling. R.S.A. organized the field work, and reviewed and edited the paper. All authors discussed results and contributed to the manuscript.

Competing interests: The authors declare no competing interests.

\section{REFERENCES}

Angélica R.S., Kahn H., Paz S.P.A. 2018. A proposal for bauxite quality using the combined Rietveld-Le Bail-Internal Standard PXRD method- Part 2: Application to a gibbsitic bauxite from the Paragominas region, northern Brazil. Minerals Engineering, 122:148-155. https://doi.org/10.1016/j. mineng.2018.03.039

ASTM. 2011. Standard practice for classification of soils for engineering purposes (unified soil classification system). West Conshohocken: ASTM international, $12 \mathrm{p}$.

Biscoe J., Warren B.E. 1942. An X-Ray study of carbon black. Journal of Applied Physics, 13:364-371. https://doi.org/10.1063/1.1714879

Bish D.L., Post J.E. 1993. Quantitative mineralogical analysis using the Rietveld full-pattern fitting method. American Mineralogist, 78:932-940.

Cao X., Prozorov R., Koltypin Y., Kataby G., Felner I., Gedanken A. 1997. Synthesis of pure amorphous $\mathrm{Fe}_{2} \mathrm{O}_{3}$. Journal of Materials Research, 12(2):402-406. https://doi.org/10.1557/JMR.1997.0058

Christidis G.E., HuffW.D. 2009. Geological aspects and genesis of bentonites. Elements, 5(2):93-98. https://doi.org/10.2113/gselements.5.2.93

DermatasD.,DadachovM.2003. Rietveld quantification of montmorillonites in lead-contaminated soils. Applied Clay Science, 23(1-4):245-255. https:// doi.org/10.1016/S0169-1317(03)00109-1
Eisenhour D.D., Brown R.K. 2009. Bentonite and its impact on modern life. Elements, 5(2):83-88. https://doi.org/10.2113/gselements.5.2.83

Eliseev A.A., Efremmov V.A., Kuzmicheva G.M., Konovalova E.S., Lazorenko V.I., Paderno Y.B., Khlyustova S.Y. 1986. X-ray structural investigation of single crystals of lanthanum, cerium, and samarium hexaborides. Kristallografiya, 31(4):803-805.

Elzea J., Murray H. H. 1994. Bentonite. In: Carr D. D. (Ed.). Industrial Minerals and Rocks. Littleton: Society for Mining, Metallurgy, and Exploration. Inc., p. 125-134.

Emmerich K., Wolters F., Kahr G., Lagaly G. 2009. Clay profiling: the classification of montmorillonites. Clays and Clay Minerals, 57(1):104-114. http://doi.org/10.1346/CCMN.2009.0570110

Gournis D., Lappas A., Karakassides M., Többens D., Moukarika A. 2008. A neutron diffraction study of alkali cation migration in montmorillonites. Physics and Chemical Minerals, 35:49-58. https://doi.org/10.1007/s00269-007-0197-z

Gražulis S., Chateigner D., Downs R.T., Yokochi A.F.T., Quirós M., Lutterotti L., Manakova E., Butkus J., Moeck P., Le Bail A. 2009. Crystallography Open Database - an open-access collection of crystal structures. Journal of Applied Crystallography, 42(4):726-729. https://doi.org/10.1107/ S0021889809016690 
Grim R.E. 1973. Technical properties and applications of clays and clay minerals. In: International Clay Conference, 1972, Madrid. Proceedings... Belgium: Association Internationale pour l'Etude des Argiles (AIPEA), p. 719-721.

Hill R.J., Howard C.J. 1987. Quantitative phase analysis from neutron powder diffraction data using the Rietveld method. Journal of Applied Crystallography, 20:467-474. https://doi.org/10.1107/S0021889887086199

Hund F., Lieck K. 1952. Das quinaere Fluorid $\mathrm{NaCaCdYF}_{8}$. Zeitschrift fuer Anorganische Allgemeine Chem, 271(1-2):17-28. https://doi.org/10.1002/ zaac. 19522710105

Le Bail A., Duroy H., Fourquet J.L. 1988. Ab-initio structure determination of $\mathrm{LiSbWO}_{6}$ by X-ray powder diffraction. Materials Research Bulletin, 23(3):447-452. https://doi.org/10.1016/0025-5408(88)90019-0

Murad E. 2010. Mössbauer spectroscopy of clays, soils and their mineral constituents. Clay Minerals, 45(4):413-430. https://doi.org/10.1180/ claymin.2010.045.4.413

Murad E., Wagner U. 1998. Clays and clay minerals: The firing process. Hyperfine Interactions, 117:337-356. https://doi. org/10.1023/A:1012683008035

Neaman A., Pelletier M., Villieras F. 2003. The effects of exchanged cation, compression, heating and hydration on textural properties of bulk bentonite and its corresponding purified montmorillonite. Applied Clay Science, 22(4):153-168. https://doi.org/10.1016/S0169-1317(02)00146-1

Odom I.E. 1984. Smectite clay minerals: properties and uses. Philosophical Transactions of the Royal Society A, 311(1517):391-409. https://doi. org/10.1098/rsta.1984.0036

Payzant E.A. 2008. Other topics. In: Clearfiel A., Reibenspies J., Bhuvanesh N. (Eds.), Principles and Applications of Powder Diffraction. Oxford: Wiley, p. 365-380.386 p.

Paz S.P.A., Angélica R.S., Neves R.F. 2012a. Mg-bentonite in the Parnaíba Paleozoic Basin, northern Brazil. Clays and Clay Minerals, 60:265-277. https://doi.org/10.1346/CCMN.2012.0600304

Paz S.P.A., Angélica R.S., Neves R.F., Neumann R., Da Costa G.M. 2011. Ocorrência de uma nova bentonita brasileira nos basaltos intemperizados da Formação Mosquito, Bacia do Parnaíba, Sul do Maranhão. Cerâmica, 57(344):444-452. https://doi.org/10.1590/S0366-69132011000400012

Paz S.P.A., Angélica R.S., Scheller T. 2012b. X ray diffraction (XRD) studies of kaolinites to support mineralogical quantification of high silica bauxites from the Brazilian Amazon region. In: International Committee for Study of Bauxite, Alumina \& Aluminium - ICSOBA, 2012, Belém. Papers, Bauxite Program, BX 16-T, 7 p.

Paz S.P.A., Kahn H., Angélica R.S. 2018. A proposal for bauxite quality using the combined Rietveld-Le Bail-Internal Standard PXRD method-Part 1: $h k l$ model developed for kaolinite. Minerals Engineering, 118:52-61. https:// doi.org/10.1016/j.mineng.2018.01.006

Rietveld H.M. 1969. A profile refinement method for nuclear and magnetic structures. Journal of Applied Crystallography, 2(2):65-71. https://doi. org/10.1107/S0021889869006558
Rodríguez-Carvajal 1993. The complete program and documentation can be obtained. Journal of Physica B, 192(1-2):55-69. https://doi. org/10.1016/0921-4526(93)90108-I

Ross C.S., Hendricks S.B. 1945. Minerals of the Montmorillonite Group. United States: United States Geological Survey Professional Paper. No 205-B, 79 p.

Scarlett N.V.Y., Madsen I.C. 2006. Quantification of phases with partial or no known Crystal structures. Powder Diffract, 21(4):278-284. https://doi. org $/ 10.1154 / 1.2362855$

Schultz L.G. 1969. Lithium and potassium absorption, dihydroxylation temperature, and structural water content of aluminous smectites. Clays and Clay Minerals, 17(3):115-149. https://doi.org/10.1346/ CCMN.1969.0170302

Souza Santos P. 1989. Ciência e Tecnologia de Argilas. $2^{\text {nd }}$ ed. São Paulo: Edgar Blücher, v. 1, 376 p.

Taylor J.C., Matulis C.E. 1994. A new method for Rietveld clay analysis. Part I. Use a universal measured standard profile for Rietveld quantification of montmorillonites. Powder Diffract, 9(2):119-123. https://doi. org $/ 10.1017 /$ S0885715600014093

Taylor J.C., Rui Z. 1992. Simultaneous use of observed and calculated standard profiles in quantitative XRD analysis of minerals by the multiphase Rietveld method: the determination of pseudorutile in mineral sand products. Powder Diffract, 7(3):152-161. https://doi.org/10.1017/ S0885715600018510

Thompson P., Cox D.E., Hasting J.B., 1987. Rietveld Refinement of Debye-Scherrer Synchrotron X-ray Data from Al2O3. Journal of Applied Crystallography, 20:79-83. https://doi.org/10.1107/S0021889887087090

Ufer K., Roth G., Kleeber R., Stanjek H., Dohrmann R., Bergmann J. 2009. Description of X-ray powder pattern of turbostratically disordered layer structures with a Rietveld compatible approach. Zeitschrift für Kristallographie, 219(9):519-527. https://doi.org/10.1524/zkri.219.9.519.44039

Ufer K., Stanjek H., Roth G., Dohrmann R., Kleeberg R., Kaufhold S. 2008. Quantitative phase analysis of bentonites by the Rietveld method. Clays and Clay Minerals, 56(2):272-282. http://doi.org/10.1346/ CCMN.2008.0560210

Van Der Marel H.W., Beutelspacher H. 1976. Atlas of Infrared Spectroscopy of Clay Minerals and their Admixtures. Amsterdam, Elsevier, $396 \mathrm{p}$

Wang X., Ufer K., Kleeberg R. 2018. Routine investigation of structural parameters of dioctahedral smectites by the Rietveld Method. Applied Clay Science, 163:257-264. https://doi.org/10.1016/j.clay.2018.07.011

Wolters F., Lagaly G., Kahr G., Nueesch R., Emmerich K. 2009. A comprehensive characterization of dioctahedral smectites. Clays and Clay Minerals, 57(1):115-133. https://doi.org/10.1346/CCMN.2009.0570111

Zhou X., Liu D., Bu H., Deng L., Liu H., Yuan P., Du P., Song H. 2018. XRDbased quantitative analysis of clay minerals using reference intensity ratios, mineral intensity factors, Rietveld, and full pattern summation methods: A critical review. Solid Earth Sciences, 3(1):16-29. https://doi.org/10.1016/j. sesci.2017.12.002 